Technology Education and Syllabus Implementation

Can Twenty Years of Technology Education assist ‘Grass Roots’ Syllabus Implementation?

Ian S. Ginns, Stephen J. Norton, Campbell J. McRobbie, \& Robert S. Davis Queensland University of Technology

Brisbane, Australia

Dr Ian Ginns

School of Mathematics Science and Technology Education

Victoria Park Road

Kelvin Grove Qld 4059

Australia

Telephone (W): $\quad 61738643339$

Telephone (H): $\quad 61733536864$

Fax: $\quad 61738643985$

Email (W): $\quad$ i.ginns@qut.edu.au

Email (H): $\quad$ ginnsfamily@aapt.net.au 
Technology Education and Syllabus Implementation

\title{
Can Twenty Years of Technology Education assist ‘Grass Roots’ Syllabus \\ Implementation?
}

\begin{abstract}
Teachers' informed acceptance of challenges associated with teaching technology might ensure the successful implementation of a Technology syllabus in primary schools. They must be prepared to analyse their own understandings of technology concepts and processes, teaching and resource needs, and engage in professional development activities designed to meet their needs. This paper investigates the introduction of a new Technology syllabus into a school and draws on a number of data sources, for example, surveys, interviews with individual teachers, classroom observations, and field notes. It was evident that very specific personal and classroom related issues (e.g., content and pedagogy), and broader issues related to the school and wider communities (e.g., resources and networking), impacted on teachers' acceptance of the syllabus. Based on these findings, the influence of twenty years of technology education and associated research on the essentials of classroom syllabus implementation by teachers is evaluated. Ways of making this store of knowledge and expertise more meaningful and accessible for teachers are explored.
\end{abstract}

Key Words: Technology Education; Technology Education Research; Technology Syllabus; Teacher Practice; Teacher Professional Development

\section{Introduction}

Both global and national efforts have been exerted over the last twenty years to develop policy related to the teaching and learning of technology in schools, and to produce associated syllabus and supporting documents (e.g., American Association for the Advancement of Science 1993; Board of Studies (Vic) 1995; Board of Studies (NSW) 1991; Curriculum Corporation 1994a; DES/Wales 1990; International Technology Education Association 2000). A major goal of these policy and syllabus documents is to ensure that all teachers engage school age students in effective technology learning experiences that challenge them to think 
Technology Education and Syllabus Implementation

in-depth about relevant technology content and processes in a learning environment that is founded on contemporary pedagogical practices.

The springboard for technology education policy development in Australia can be ascribed Formatted: Not Highlight to an agreement, referred to as the Hobart Declaration, forged in 1989 by the Australian Education Council (1989), a body comprised of the ministers of education of all states, territories, and the commonwealth. An outcome of the agreement was that all parties would work towards a common curriculum framework for Australia in eight Key Learning Areas one of which was a new learning area called Technology. It was also agreed that the curriculum for each Key Learning Area (KLA), when developed, should be outcomes based which reflected international trends at that time.

A national collaborative effort, guided by the AEC, to produce national statements and profiles in each Key Learning Area (e.g., A Statement on Technology for Australian Schools, Curriculum Corporation 1994a; Technology - A Curriculum Profile for Australian Schools, Curriculum Corporation 1994b) was launched after the Hobart Declaration. In common with other Key Learning Areas, it was intended that the technology statement and profile would, respectively, provide a common framework for curriculum development throughout Australia and provide guidelines for judging students' progress in technology. However, this bold vision of a national common framework for curriculum development was unrealised as each state and territory, with the exception of Queensland, commenced its own curriculum development processes based on its own interpretation of the published national statements and profiles. A summary of the major similarities and differences of the state and territory technology curriculum documents compared to the respective national statement and profile were prepared as part of the design brief for a new technology syllabus in Queensland (Queensland Schools Curriculum Council 1998). 
Technology Education and Syllabus Implementation

The recognition of technology as a key learning area and planning for the development of appropriate curriculum materials in Queensland occurred somewhat later in comparison with other states and territories of Australia. Based on the national statement and profile, the perspective of technology enunciated in the new Queensland Years 1 to 10 syllabus is as follows: "Technology involves envisioning and developing products to meet human needs and wants, capitalise on opportunities and extend human capabilities,” (Queensland Studies Authority, 2003, p. 1). This perspective of technology is in accord with perspectives of technology espoused in policy and syllabus documents of other states and territories, and other countries. The final version of the syllabus was introduced in 2003, with full implementation in all schools across Queensland occurring over a period of three years. In order to ensure the successful introduction of the syllabus, it is important teachers develop an informed acceptance that this new learning area can make a worthwhile contribution to students' understandings of technology concepts and processes, their technological capabilities, and their development into lifelong learners. In effect, all students should acquire a basic understanding of technology and its impact on society (Custer 1995).

Such an assertion implies that teachers should possess a personal knowledge and understanding of the content and processes of design and technology, and possess related pedagogical content knowledge and pedagogical knowledge that will guarantee the successful implementation of any technology syllabus and ensure students' attainment of a basic understanding of technology. Further, it implies that teachers must be aware technological activity can be conducted in a variety of contexts and in a variety of ways. Teachers should also be cognisant of the thinking students engage in, when problem solving in technology, if they are to capitalise on critical incidents where students may refer directly, or indirectly, to the content and processes of technology, and to engineering and scientific principles (Stein et al. 2002). 


\section{Technology Education and Syllabus Implementation}

\section{Twenty years of technology education}

Twenty years of technology education and associated research have provided much information about primary school teachers' personal capacity and capabilities for teaching technology, although only a small portion of relevant literature will be drawn upon for the purposes of this paper. Where technology education has been introduced as a learning area in other parts of the world over the past twenty years, primary school teachers have experienced a variety of difficulties. These difficulties have been related to practicing teachers' (Elton 2005; Jarvis \& Rennie 1996) and preservice teachers’ (McRobbie et al. 2000) limited understanding of the phenomenon of technology; a limited understanding of technology concepts and processes (Holroyd \& Harlen 1996; Parkinson 2001); their struggles to conceptualise the whole technology learning area in line with national frameworks (Mittell \& Penny 1997; Stein et al. 2002); their limited knowledge of specific tool and practice skills (Anning 1994); and a low level of confidence in their ability to teach technology and lack of personal experiences with the area (e.g., Australian Science Technology and Engineering Council (ASTEC) 1997; Elton 2005; Holroyd \& Harlen 1996). It is possible that many teachers in Queensland will face identical challenges as they endeavour to conceptualise the teaching and learning of a new subject area in a variety of contexts.

In what ways can 20 years of technology education and associated research help classroom teachers? Again, only a small portion of relevant literature related to technology knowledge, technology processes, and pedagogical issues will be surveyed here. The notion of a technology knowledge base for teachers is pivotal for effective teaching of technology (Jones et al. 2001). A feature of their study was the development of a planning format for teachers that would assist them to identify specific concepts they would cover in different technology areas. In addition, Jones and Moreland (2004) reported positive outcomes from using planning formats and cognitive tools to enhance teachers’ pedagogical content knowledge. McCormick (1997) has 
Technology Education and Syllabus Implementation

drawn attention to the importance of conceptual knowledge, particularly in its relationship to procedural knowledge, and, in a subsequent paper (McCormick 2004), explored three interrelated issues of relevance to teachers. McCormick articulated responses to these issues which we have presented here as three questions: what is the nature of technological knowledge; what is the relationship between knowledge and situated learning; and how is the learning that takes place related to context?

It has been acknowledged that technology processes (or the design process) are complex and may be described as cyclical or recursive (Johnsey 1995; Kimbell et al. 1996; Kimbell \& Parry 2001). Investigations into the classroom activity of novice students attest to the complexity of the design process (Welch 1999; Welch \& Lim 2000; Welch et al. 2000) and have important implications for what teachers might expect as they challenge students with design briefs. Lee and Todd (2004) also acknowledge the importance of the design process and have presented evidence of the effectiveness of several strategies teachers can employ to support students in the formative stages of designing. The ways teachers in two countries translated curriculum requirements for teaching design in the classroom have been investigated by Hill and Anning (2001). They noted differences between teachers' and students' designerly thinking and behaviours and the designerly thinking of professional designers and labelled these respectively as 'school situated design' and 'workplace design.' The fine-grained analysis of designerly thinking and actions of preservice teachers as they worked on open-ended technology projects, conducted by McRobbie et al. (2001), provided rich insights into the design processes adopted by the teachers and the findings have implications for preservice and inservice programs. In a similar study of primary school students, McRobbie et al. (2000) concluded that the fine-grained analysis of the students' designerly thinking and actions could inform educators about how they might enhance the 
Technology Education and Syllabus Implementation

competence and confidence of teachers to assist students with the design process resulting in improved learning outcomes for their students.

Wilson and Harris (2003), in their analysis of effective teaching and learning of design and technology, reviewed a number of pedagogical issues that confront classroom teachers. For example, Wilson and Harris referred to Hennessy and Murphy's (1999) belief that collaborative learning is insufficiently used as a teaching method by teachers. Further, Murphy and Hennessy (2001) suggested that for collaboration to be effective teachers must have a range of activities prepared which cater for individual needs and various time commitments. However, the routine use of group work in technology cannot be described as collaboration (Wilson \& Harris 2003), and Burgess (1998) questioned the efficacy of lower ability students working with higher ability students in groups. Both low and high ability students derived positive benefits in the form of increased motivation and self-image from a scientific-technological problem based learning approach Doppelt (2003), a result in accord with findings from prior studies into meaningful learning through problem based learning (Barak \& Doppelt 2000; Doppelt \& Barak 2002). Similarly, positive benefits were derived by students with limited experiences using construction materials from the classroom use of structured teaching-learning packages for explanation or constrained problems (Doornekamp 2001), and Twyford and Jarvinen (2000) have described the benefits for students when teachers employed open-ended but focused teaching approaches. However, Ginestié (2002) cautions that although guided approaches may allow students to experience success by choosing a teacher's predetermined solution, their learning may be inadequate compared to learning through engagement in more open ended approaches where many solutions to a problem may be possible. Other studies indicate that teachers should be encouraged to allow for more 'risk taking' in technological activity (McCormick \& Davidson 1996), and foster higher order thinking and questioning capabilities in students (Stables 1997). 
Technology Education and Syllabus Implementation

The above survey and analysis of a small portion of relevant literature related to technology knowledge, technology processes, and pedagogical issues over the last twenty years provides a backdrop to the research study described in this paper. A project was conducted to investigate the introduction of the new Technology syllabus into one Queensland school and the outcomes of the study are reported in this paper. The school was one of 10 selected by Education Queensland to play a leadership role in the full state-wide implementation of the syllabus. The objectives of this paper are: (a) to identify and analyse the initial and ongoing issues affecting teachers as they tackled the implementation of the new technology syllabus; and (b) to evaluate the effect of twenty years of technology education and associated research on the essentials of classroom syllabus implementation. 
Technology Education and Syllabus Implementation

\section{Methods and Techniques}

In order to understand the purposes and meanings the participants in the study attached to their statements and actions, an interpretive research methodology was adopted by the researchers (Erickson 1998). The collection and analysis of data were guided by employing the criteria of trustworthiness, authenticity and the benefits of the hermeneutic process (Lincoln \& Guba 2000). Triangulation, involving the use of multiple data sources, ensured the probability that emerging assertions were consistent with a variety of data was maximised.

\section{Participants}

The participants were eight teachers ( 7 females; 1 male) and the principal (female) of a small Grades 1 to 10 rural school (Farmland State School - a pseudonym) in Queensland. The teachers normally taught composite classes in the primary school from Grades 1 to 6 (e.g. composite class of Grade 1 and 2 students; composite class of Grade 3 and 4 students), and/or specialist subject areas in the middle school from Grades 7 to 10 (e.g. English; Science; Mathematics; Business Education; Home Economics Education). The names of the principal and teachers reported in the Findings section and subsequent discussion are pseudonyms. Farmland school was designated as a leading school in Technology approximately five months prior to the commencement of the research study. The principal expected all teachers to implement one or more technology units of work each semester. The research study commenced at the beginning of the school year at approximately the same time as most teachers began teaching their first technology unit of work.

\section{Data sources}

Initially, a meeting was held with all staff and the principal of Farmland State School to explain the research project and negotiate the extent of teacher, principal and researcher involvement. Immediately after the first meeting, all participants completed the survey instrument, Technology Syllabus Implementation Questionnaire (TSIQ). This instrument, 
Technology Education and Syllabus Implementation

described in more detail in the next section, was used to probe teachers' perceptions of their capabilities to implement the Technology syllabus and the capacity of the school administration and school environment to support their implementation of the syllabus. The principal completed a modified version of TSIQ designed for school administrators.

Other data sources included formal and informal interviews with teachers at the commencement, and during the implementation of their technology units of work. They were asked to reflect on issues affecting the implementation of the unit, and their ongoing needs for personal and professional support. Teachers also reflected on the role of administration, the school culture and environment, and resources and activities required to foster their continued professional development. The formal and informal interviews were audiotaped. Additional data sources included classroom observations collected using videotaping and audiotaping techniques, and field notes. Artefacts including planning documents and resources used were also collected.

The intensive data collection lasted for a period of one semester, approximately 20 teaching weeks, and concluded with formal, audiotaped interviews. The teachers were asked to review the full implementation of the Technology syllabus in their school and articulate the ongoing learning and organisational needs required to ensure their progress towards becoming autonomous professionals and curriculum developers capable of sustaining innovation and change in this new area of Technology. The teachers and principal completed TSIQ for a second time.

\section{The TSIQ instrument}

The TSIQ instrument (Part A) was adapted from the Science Curriculum Implementation Questionnaire devised by Lewthwaite (2004). The main adaptations were changing all references to science to the term technology, and changing references to teachers in general to "I" statements in a number of items. Similar to the source instrument, TSIQ consists of 49 
Technology Education and Syllabus Implementation

items and 7 scales, with 7 items for each scale. An individual teacher's perceptions were determined on a 5 point Likert scale ranging from 1 (Strongly Disagree) to 5 (Strongly Agree). Important attributes of TSIQ are shown in Table 1.

Table 1

Key Attributes of the TSIQ Instrument (Part A)

\begin{tabular}{|c|c|c|}
\hline Scale & Description & Sample Item \\
\hline Teacher Knowledge (TK) & Content and pedagogical issues & $\begin{array}{l}\text { Item 36: I have a good background } \\
\text { knowledge for teaching technology }\end{array}$ \\
\hline Professional Interest (PI) & Motivation and attitude issues & $\begin{array}{l}\text { Item 2: I have a positive attitude to the } \\
\text { teaching of technology }\end{array}$ \\
\hline Professional Adequacy (PA) & $\begin{array}{l}\text { Preparation, competence and } \\
\text { confidence issues }\end{array}$ & $\begin{array}{l}\text { Item 4: I am adequately prepared to } \\
\text { teach technology }\end{array}$ \\
\hline Resource Adequacy (RA) & $\begin{array}{l}\text { Resource, facilities, and access } \\
\text { issues }\end{array}$ & $\begin{array}{l}\text { Item 3: I am well resourced for the } \\
\text { teaching of technology }\end{array}$ \\
\hline Professional Leadership (PL) & $\begin{array}{l}\text { Administration access and school } \\
\text { ethos issues }\end{array}$ & $\begin{array}{l}\text { Item 40: I perceive that technology as a } \\
\text { syllabus area is valued at this school }\end{array}$ \\
\hline Time (Ti) & $\begin{array}{l}\text { Adequate time for planning and } \\
\text { teaching issues }\end{array}$ & $\begin{array}{l}\text { Item 20: My technology teaching suffers } \\
\text { because the overall school curriculum is } \\
\text { crowded }\end{array}$ \\
\hline Professional Support (PS) & $\begin{array}{l}\text { Professional development and } \\
\text { collegial support issues }\end{array}$ & $\begin{array}{l}\text { Item 7: I have the opportunity to receive } \\
\text { ongoing technology syllabus } \\
\text { professional support }\end{array}$ \\
\hline
\end{tabular}

The scales Teacher Knowledge (TK); Professional Interest (PI); and Professional Adequacy (PA) refer to teachers' personal perceptions of their capabilities, motivation, competence and confidence to implement the Technology syllabus. Four scales refer to teachers’ perceptions of technology syllabus implementation within the school environment Resource Adequacy (RA); Professional Leadership (PL); Time (Ti); and Professional Support (PS). The alpha reliability for each scale, ranged from .77 to .92 for the source instrument (Lewthwaite 2004), which suggested that TSIQ-Part A should be a valid instrument for use in the context of this research.

It is contended that individual mean scale scores at, or below, a middle score $(<$ or $=3.0)$ for Teacher Knowledge, Professional Interest, and Professional Adequacy may be interpreted 
Technology Education and Syllabus Implementation

as being indicators of issues related to teachers' expressed personal needs associated with the respective scale. For example, a teacher with a low mean score for the scale Teacher Knowledge may be expressing a need for a better understanding of technology concepts and processes and/or how to teach the subject. Similarly, individual mean scale scores for Resource Adequacy, Professional Leadership, Time, and Professional Support could be construed as being indicative of issues related to the needs of teachers with regard to the school environment (e.g. teaching and resource needs).

Open-ended questions devised by the researchers were attached to the TSIQ to form Part-B of the instrument. These questions probed teachers' perceptions of the major factors that were contributing to the effective implementation of the new Technology syllabus; what were the main barriers preventing or inhibiting the effective implementation of high quality technology programs; and a request for further comments of an unspecified nature.

\section{Data analysis}

The individual mean scale scores for each teacher and the principal for each scale on TSIQ were calculated. The overall mean scale score for each scale and corresponding standard deviations were calculated for the teachers as a group.

The qualitative data were analysed for evidence of the impact of content and pedagogical issues (e.g. technology content knowledge; knowledge of the Technology syllabus; and how to teach technology) on teachers' planning and implementation of technology learning experiences. Evidence of teachers' needs associated with professional development and requirements for administrative and other forms of support within the school environment was also sought. Data on teachers' participation in professional development activities were analysed to determine the nature and frequency of those activities; and the effects of professional development activities on their planning and practice. The nature and impact of the school principal's role on the implementation of the syllabus were also analysed. 
Technology Education and Syllabus Implementation

\section{Professional development activities}

The professional development activities the teachers engaged in, from the announcement that the school had been nominated as a leading school in Technology to the conclusion of the research study, are outlined in summary form in Table 2. The activities are shown in approximate chronological order over a period of nine months and the activities initiated by the school principal are also identified.

The sequence of professional development activities began with the attendance of teachers from approximately 30 schools at an initial School District inservice program organised by the principal of Farmland State School. The focus of the one-day inservice was an initial examination of the main features of the syllabus and the implications for teaching and learning technology. Three cluster school groups were formed at that time with Farmland being appointed as mentor school for one cluster. Cluster school meetings were held on a number of occasions to review progress on planning and implementation of the syllabus. Technology units of work prepared by teachers at Farmland were used as exemplars for analysis and critique at these meetings.

Three teachers from Farmland school attended the launch of the leading schools in Technology project hosted by Education Queensland. Teachers and principals from the ten leading schools gathered at the conference to be briefed about the project, and to share ideas about how they would proceed with the implementation of the Technology syllabus in their respective schools.

The researchers conducted a one-day professional development workshop at Farmland school. A number of facets of technology education were explored including: understanding the curriculum specifications and structure (e.g., strands; core learning outcomes); investigating technology concepts and processes through activity work (e.g., testing the 
Technology Education and Syllabus Implementation

strength of materials); and strategies for authentic assessment. In addition, a member of the research team (RSD) worked actively with the teachers for the second half of the semester. The researcher provided guidance and advice for planning and implementation of technology units of work and was present in the classroom during a number of the learning experiences. Particular attention was paid to assisting teachers with the assessment of student learning during, and at the completion of, the units of work.

Table 2

Summary of Farmland Teachers Engagement in Professional Development Activities

\begin{tabular}{|c|c|c|}
\hline Description of PD program & Nature of PD program & Initiator \\
\hline School district inservice (1 day) & $\begin{array}{l}\text { Working with new Technology } \\
\text { syllabus }\end{array}$ & School principal - Farmland \\
\hline Innovator schools meeting - & Conference comprising all & Education Queensland (EQ) \\
\hline Brisbane (2 days) & Innovator Schools in Technology & \\
\hline Cluster school meeting (1 day) & $\begin{array}{l}\text { Use of syllabus outcomes and } \\
\text { elaborations }\end{array}$ & School principal - Farmland \\
\hline $\begin{array}{l}\text { Mentoring activities with cluster } \\
\text { schools }\end{array}$ & Planning and implementation & School principal - Farmland \\
\hline $\begin{array}{l}\text { In-school staff professional } \\
\text { development ( } 1 / 2 \text { day) }\end{array}$ & Practical planning activities & $\begin{array}{l}\text { School principal - Farmland; small } \\
\text { group of teachers - Farmland }\end{array}$ \\
\hline QUT staff development day & $\begin{array}{l}\text { Practical activities linked to } \\
\text { syllabus strands }\end{array}$ & QUT \\
\hline $\begin{array}{l}\text { Formation of teacher working } \\
\text { groups (ongoing) }\end{array}$ & $\begin{array}{l}\text { Fine grained planning and } \\
\text { preparation }\end{array}$ & School principal - Farmland; teachers \\
\hline $\begin{array}{l}\text { Two cluster school meetings - } \\
\text { offsite ( } 1 \text { day each) }\end{array}$ & Sharing planned units of work & $\begin{array}{l}\text { School principal - Farmland; small } \\
\text { group of teachers - Farmland }\end{array}$ \\
\hline $\begin{array}{l}\text { Community involvement design } \\
\text { activity ( } 1 / 2 \text { day) }\end{array}$ & $\begin{array}{l}\text { Working with the local } \\
\text { community }\end{array}$ & $\begin{array}{l}\text { School principal - Farmland; all } \\
\text { teachers }\end{array}$ \\
\hline $\begin{array}{l}\text { Involvement of research team } \\
\text { member (one term) }\end{array}$ & $\begin{array}{l}\text { Active engagement of one } \\
\text { researcher in classrooms }\end{array}$ & QUT \\
\hline $\begin{array}{l}\text { Peer mentoring in classrooms } \\
\text { (ongoing) }\end{array}$ & $\begin{array}{l}\text { One-to-one engagement of key } \\
\text { teachers with other teachers }\end{array}$ & $\begin{array}{l}\text { School principal - Farmland; small } \\
\text { group of teachers }\end{array}$ \\
\hline Teleconferencing (ongoing) & $\begin{array}{l}\text { Regular link-up between } \\
\text { Innovator Schools }\end{array}$ & EQ \\
\hline Email groups (ongoing) & $\begin{array}{l}\text { Formation of information } \\
\text { exchange network between } \\
\text { members of the group }\end{array}$ & $\begin{array}{l}\text { School principal - Farmland; small } \\
\text { group of teachers - Farmland; } \\
\text { teachers in other schools; EQ }\end{array}$ \\
\hline
\end{tabular}

Two teachers at the forefront of Technology syllabus implementation at Farmland school conducted intensive one-to-one mentoring sessions with selected other teachers in the school. In these sessions, the mentor teachers provided specific advice and support for the planning of technology units of work and assisted with the classroom implementation of those units. 


\section{Technology Education and Syllabus Implementation}

\section{Findings}

In the first part of the Findings section of the paper, the quantitative data presented in tabulated format are examined to identify the initial and ongoing issues affecting teachers as they planned and implemented the new Technology syllabus. Instances where individual scale means are less than or equal to 3.0 are analysed and any claims are substantiated through links with qualitative data from TSIQ-Part B and informal and formal interviews. In the second part of the Findings section of the paper, qualitative data from classroom observations, field notes, and informal and formal interviews are examined to determine if, and in what ways, teachers' classroom practices had changed as an outcome from the totality of their experiences, for example, engagement in professional development activities, and practical implementation of technology learning experiences.

\section{Teachers' perceptions}

The individual pre- and posttest mean scale scores on TSIQ-Part A for each teacher for each scale are shown in Table 3, along with the scale means and corresponding standard deviations for the group of eight teachers. Mean scale scores for the Principal of Farmland State School (Lyn) are included in the table for reference purposes. In the table the first number in each column represents the mean score of each teacher's pretest responses for each scale, while the second number represents the mean score of each teacher's posttest responses for each scale. 
Technology Education and Syllabus Implementation

Table 3

Individual Teacher and Group Mean Scale Scores for Each Scale on TSIQ-Part A

\begin{tabular}{lccccccc}
\hline Teacher & TK $^{*}$ & PI $^{*}$ & PA $^{*}$ & RA $^{*}$ & PL $^{*}$ & Ti $^{*}$ & PS $^{*}$ \\
\hline Bella & $4.1: 4.1$ & $4.1: 4.4$ & $4.0: 4.4$ & $4.1: 4.4$ & $4.0: 4.3$ & $4.0: 3.7$ & $4.1: 3.9$ \\
Celine & $1.6: 2.0$ & $2.9: 2.9$ & $1.9: 2.1$ & $2.0: 2.1$ & $3.9: 3.9$ & $1.0: 2.3$ & $2.6: 2.6$ \\
Doris & $4.0: 4.0$ & $4.1: 4.1$ & $4.0: 4.0$ & $4.0: 4.0$ & $5.0: 4.1$ & $4.0: 2.0$ & $4.6: 3.7$ \\
Eve & $1.0: 3.9$ & $2.9: 3.1$ & $1.3: 3.4$ & $2.0: 3.9$ & $3.9: 4.7$ & $1.3: 3.9$ & $3.1: 3.9$ \\
Arthur & $2.7: 3.4$ & $3.7: 4.0$ & $3.4: 3.9$ & $4.0: 4.1$ & $4.0: 4.0$ & $4.0: 3.3$ & $4.4: 4.1$ \\
Helen & $4.0: 4.0$ & $4.0: 4.0$ & $3.9: 4.1$ & $3.7: 4.0$ & $3.9: 4.1$ & $4.0: 4.0$ & $4.0: 4.0$ \\
Jan & $2.4: 2.4$ & $3.1: 3.6$ & $2.4: 3.3$ & $3.6: 3.3$ & $4.1: 4.6$ & $2.3: 2.6$ & $3.0: 3.4$ \\
Kay & $3.1: 4.0$ & $5.0: 5.0$ & $3.4: 4.1$ & $3.9: 3.0$ & $4.9: 4.1$ & $3.7: 3.4$ & $3.4: 3.7$ \\
Group Scale Means & $2.9: 3.5$ & $3.7: 3.9$ & $3.0: 3.7$ & $3.4: 3.6$ & $4.2: 4.2$ & $3.0: 3.1$ & $3.7: 3.7$ \\
Group SD & $1.2: 0.8$ & $0.7: 0.7$ & $1.0: 0.7$ & $0.9: 0.8$ & $0.5: 0.3$ & $1.3: 0.8$ & $0.7: 0.5$ \\
Lyn ${ }^{*}$ & $3.6: 4.0$ & $4.7: 4.4$ & $3.3: 3.9$ & $4.6: 4.1$ & $4.9: 5.0$ & $4.3: 4.9$ & $4.9: 4.6$ \\
\hline * See Table 1 for elaboration of scale codes & & & & & \\
${ }^{*}$ The Principal of Farmland State School & & & & &
\end{tabular}

Overall mean scores for the scales Teacher Knowledge, and Professional Adequacy showed marked increases from the pretest to the posttest administrations of TSIQ, with marginal or no increases for the remaining scales. With the exception of Professional Interest, all standard deviations decreased indicating a reduction of the spread for those scales with teachers who initially responded in the least positive way, tending to respond more positively at the end of the study (e.g., Celine, Eve, and Jan). The reduction of spread was most evident for the scales Teacher Knowledge, Professional Adequacy, Professional Leadership, and Time. The pre- and posttest mean scale scores for the Principal of Farmland State School, exceeded the group scale means on all scales.

A comparison of the individual mean scale scores indicates relatively minor changes for most teachers, however, some teachers showed notable improvement. In particular, Celine and Eve reported improved perceptions of the school environment concerning time constraints, and Eve reported improvements in her personal perceptions of her teacher 
Technology Education and Syllabus Implementation

knowledge, professional adequacy, and perceptions of the school resource adequacy. Bella, Doris and Helen reported relatively high initial and final mean scores on each scale.

Responses to open-ended questions in Part-B of the TSIQ instrument and interview questions provided insights into possible reasons for teachers' individual mean scores on each scale. For example, Celine with a low pretest score on the Teacher Knowledge scale ((TK) Pretest: M=1.6) indicated that "Knowledge of the KLA and syllabus" was of concern to her. Her professional adequacy ((PA) Pretest: $M=1.9)$ expressed as a need for professional development in order "to know what I need to do and how to do it," along with a perceived lack of teacher knowledge, concerns about "Resource availability and access,” ((RA) Pretest: $\mathrm{M}=2.0$ ) and time constraints ((Ti) Pre: $\mathrm{M}=1.0$ ), appeared to represent the main barriers inhibiting the effective implementation of quality technology teaching units in her classroom. Celine’s perceptions of her teacher knowledge improved marginally to a mean scale score of 2.0 in the posttest. She reiterated her uncertainties about her personal teacher knowledge by claiming, "I have a lack of depth in background knowledge and the strategies for teaching technology.” Her previous concerns about her knowledge of the KLA and syllabus documents were not referred to at the end of the study. While Celine's perceptions related to time constraints eased ((Ti) Pretest: $M=1.0$; Posttest: $M=2.3)$, they remained an important feature of her thinking about teaching technology, "It is the extra effort, on teachers' behalf, to research and design a program of instruction to cater for integrated learning tasks.” Celine’s personal perceptions of her own professional interest, professional adequacy, the school resource adequacy, and professional support offered by the school showed negligible improvements over the period of the study.

Eve's initial perceptions of her teacher knowledge ((TK) Pretest: $M=1.0)$ were summed up by her expressed need for “A comprehensive knowledge and understanding of methodologies of technology," and a "Lack of understanding” being a major barrier for implementing high 


\section{Technology Education and Syllabus Implementation}

quality technology education programs. Her low initial scores on the scales Teacher Knowledge, Professional Adequacy, Resource Adequacy, and Time had undergone substantial gains by the end of the study. Despite the improvement in her score for the scale Time ((Ti) Pretest: $\mathrm{M}=1.3$; Posttest: $\mathrm{M}=3.9)$, Eve remained concerned about this issue stating, "Even though technology is integrated into other KLAs, there is still time taken away from these for technology which can be detrimental to the KLA and the students.” There were small changes in Eve's perceptions of her personal professional interest in technology and the professional support offered to her by the school.

Jan recorded low initial mean scores for three scales Teacher Knowledge, Professional Adequacy, and Time. She indicated some unease with her own capabilities at the outset of the study when comparing herself with "Some teachers (who) have had inservice and are confident and competent.” However, an increase in Jan’s scores for professional interest ((PI) Pretest: $M=3.1$; Posttest: $M=3.6$ ), reflected in her "Key willingness to try" teaching technology, may, in part, account for the increase in her perceptions of her professional adequacy ((PA) Pretest: $M=2.4$; Posttest: $M=3.3)$. There was no change in Jan's score for the Teacher Knowledge scale. Jan expressed the view that time was the major barrier inhibiting the effective implementation of technology programs ((Ti) Pretest: 2.3; Posttest: 2.6), a perception in accord with those of Celine and Eve described previously, and, in particular, Doris who identified, at the finish of the study, that the implementation "Timeframe and curriculum workload” had been major problems for her ((Ti) Pretest: 4.0; Posttest: 2.0).

Arthur recorded a low pretest score for the scale Teacher Knowledge ((TK) Pretest: $\mathrm{M}=2.7)$. His general "limited understanding” of technology (pretest) was refined to a more specific "lack of understanding in the areas of systems and information," at the end of the study ((TK) Posttest: M=3.4). It was interesting to note that Kay’s perceived difficulties with "Understanding how the syllabus (works) through the levels," ((TK) Pretest: M=3.1) were not 
Technology Education and Syllabus Implementation

raised as an issue in the posttest ((TK) Posttest: M=4.0). At the end of the study, Kay's comments were directed towards asserting that an adequate supply of "resources, tools and materials,” were essential for technological activity which may account for a decrease in her score ((RA) Pretest: $M=3.9$; Posttest: $M=3.0)$ for the scale Resource Adequacy.

All individual pre- and posttest scores for the scale Professional Leadership were high (> or =3.9) suggesting that there were few, if any, perceived needs associated with the school administration and school culture of support for the implementation of the new Technology syllabus. Eve noted the positive effect of the "drive from administration" on the acceptance of the new syllabus into the teachers' overall teaching programs ((PL) Pretest: M=3.9; Posttest: $M=4.7)$. Classroom observations revealed that all teachers in the school implemented one or more technology units of work during the period of the study. Helen, in accord with Eve and Doris, referred to strong administrative leadership, commitment and urging that "Everybody has to have some sort of technology focus in their units of work, every teacher in the school is doing it in some way.” However, Doris ((PL) Pretest: $M=5.0$; Posttest: $M=4.1)$ and Kay ((PL) Pretest: $\mathrm{M}=4.9$; Posttest: $\mathrm{M}=4.1$ ) did record lower scores on this scale at the end of the study.

Celine’s ((PS) Pretest: M=2.6) and Jan’s ((PS) Pretest: M=3.0) relatively low mean scores for the Professional Support scale showed minor or no, change over time. Only Celine drew attention to her need for professional development. Other teachers, for example, Doris acknowledged the value of "School support from administration to teachers who have not had the opportunity to attend professional development (activities)," although her score for the scale dropped ((PS) Pretest: $\mathrm{M}=4.6$; Posttest: $\mathrm{M}=3.7)$, and Arthur ((PS) Pretest: $\mathrm{M}=4.4$; Posttest: $M=4.1$ ) perceived that he had benefited from the "Support of other teachers and having the chance to ask questions and raise ideas for teaching technology.” 
Technology Education and Syllabus Implementation

\section{Change in teacher practice}

All teachers succeeded in meeting the Principal's requirement that they implement at least one technology unit of work in the semester. Some examples of technology units taught by the teachers at Farmland State School were construction of bird accommodation for the school (Arthur), bird feeders (Kay), quilt making (Bella), construction of land yachts out of Lego (Eve), and collages (Doris). The totality of teachers' experiences which included a variety of professional development activities and the practical implementation of technology units of work in the classroom resulted in changes in their practice.

The assertion that teachers' classroom practice had changed was found in the voices and actions of the teachers themselves. The changes in classroom practice are examined in detail for two teachers (Arthur; Eve), followed by a brief summary of other noted changes. Quotes used are drawn from informal and the final interviews.

Arthur: Arthur's first attempt at implementing a technology unit of work with his Grade 5/6 students was the design and construction of bird accommodation for the school. It was also his first attempt at using a problem solving approach in any subject that he had taught. Arthur resorted to a strategy he termed a design challenge, a way of challenging students' thinking he had discovered in in-school staff professional development activities and the first cluster school professional development meeting he had attended. The strategy involved presenting the students with a scenario, which he wrote on the whiteboard. Kay, a colleague primary teacher at the school, had informed him, previously, that the "Students would come up with the ideas.” Although initially sceptical, he was convinced when "The kids just rattled off twenty to twenty-five odd things that they will have to learn in order to solve the problem, and it was spot on, exactly what we had planned for. It was good.” 


\section{Technology Education and Syllabus Implementation}

Arthur noted another change in his practice when he expressed the belief that he was not directly teaching a large amount of content any more. He remarked:

It hit me today. I don't find myself teaching these children a lot of content. I think they find it out for themselves. You do not write it on the board and get them to copy it down. They have a lot more ownership of their learning. You have to really lay your trust in the kids, and it seems to be working. A child went down to the public library who would never step in the library before, but he needed the information for his project.

The day-long professional activity provided by the researchers involved an examination of ways of testing the strengths of various materials. A number of fibres were tested to breaking point by the controlled addition of various weights. Arthur capitalised on the usefulness of considering relevant material properties in the bird accommodation technology unit of work. Working with the secondary school technology teacher who had expertise in the properties of materials, Arthur encouraged his students to test the suitability of a variety of timbers from which the bird accommodation could be constructed. He observed:

The children looked at the properties of strength, flexibility, and durability (of the timbers). Some children even boiled theirs in hot water to simulate (weathering) them further. Then we came up (with the decision) that pine was very good.

These exemplars of classroom and interview evidence support Arthur's own conclusion that his classroom practice had changed and he was "Really trying something different that I’ve never tried before. It seems to be working.”

Eve: Eve also used to advantage the practical testing by students of materials for the construction of parachutes and indicated that "It gave me ideas for the parachutes and things which we did.” Her Grade 7 students tested the strength of cottons and other materials in order to make judgments about their suitability for parachute cords, and used a "Similar technique to check the materials they were using for the canopy for the parachutes." In addition, possible materials for the parachute cords were tested to determine if they stretched under a weight equivalent to the load the parachutes had to transport safely to the ground. Eve 
Technology Education and Syllabus Implementation

talked the students through the elements of fair testing procedures and the need to control variables. Pieces of different materials, measuring $15 \mathrm{~cm}$ x $15 \mathrm{~cm}$, for the parachute canopy were tested by dropping them from an upper level school veranda to "See how they floated down and held their shape.” After conducting all the tests Eve noted:

They have to come up with three design options, choose one and then write down why they’ve chosen that particular one. They’ve got to have scientific reasons in there (their report), not just the fact that they like the pretty material. Then, as they're actually building, making the parachute, they have to put down the things that went right, what went wrong, why it went wrong, do we have to make minor changes, why?

Through these processes, Eve believed that she had established an open-ended approach to solving the problem. She stated:

I have left it deliberately (open-ended). And some of them, especially the Grade 8s are saying, 'But what if it’s wrong?' I say 'It’s not necessarily wrong. It's deliberately left for you to use your imagination, so if it works, it works. There's no right or wrong and that is something that's difficult for them to understand. It's always been, there's a right way or wrong way. We'll see what happens.'

Eve, in acknowledging the mentoring efforts of Bella, one of the teachers at the forefront of syllabus implementation at the school, stated "At the end of term one, we got together. We sat down and we planned how we would do the grade 8/9 unit and I guess I've used the basis of that for the 7s (parachutes unit). It sort of was a way of showing us how to go about it.” Eve said she was spurred on to come to grips with the technology syllabus outcomes and how they could be integrated into the unit plan. Not content with her initial attempt at matching outcome statements and relevant levels of student learning, Eve sought further advice and clarification from the Lyn, the Principal. Subsequently, during a holiday period and with time to think in greater depth about unit planning Eve believed that she had "Pulled it all together," forming the elements of planning for teaching technology into a coherent framework that she could understand and use in her classroom. 
Technology Education and Syllabus Implementation

Other instances where teachers reported the incorporation of ideas from professional development activities are summarised as follows: design challenges (e.g. Kay); design portfolios (e.g. Bella; Kay); and assessment criterion sheets (e.g. Kay; Eve; Arthur). Kay, Bella, Helen and Arthur were provided with the opportunity to present their units of work for critical analysis and discussion at cluster school and School District meetings with other teachers.

\section{Discussion}

In this section of the paper we will analyse the initial and ongoing issues evident in the findings that affected teachers' implementation of the new technology syllabus, and evaluate the effect of twenty years of technology education and research on the essentials of classroom syllabus implementation.

Qualitative and quantitative data from a variety of sources indicate that very specific personal and classroom issues (e.g., content; pedagogy) and broader issues related to the school environment and wider communities (e.g., resources; time; group networks) appeared to influence teachers' acceptance of challenges embodied in the new technology syllabus. Initially, content and pedagogy issues were reflected in comments that referred to a need for knowledge about the new syllabus and its structure, and understandings about the content and processes of technology. Indeed, these issues may have caused three teachers to question their competence and confidence to teach technology.

Teachers' overall interest in, and motivation to, implement the new syllabus remained high throughout the study. Their motivation and positive attitudes may have been sustained through the school principal's professional leadership, commitment and ongoing support for the full implementation of the new technology syllabus. Therefore, the totality of personal and professional experiences may account for positive changes in most teachers' perceptions of their knowledge of technology content and processes, knowledge of the syllabus, and 
Technology Education and Syllabus Implementation

competence and confidence to teach technology. However, it is of concern that, in spite of the provision of extensive external and in-school professional development activities, including one-to-one peer mentoring sessions, two teachers still perceived that their technology content and pedagogical knowledge was inadequate.

With regard to broader issues related to the school environment, the majority of teachers rated the resource adequacy of the school as high. However, there were signs that some teachers, whose perceptions regarding the usefulness of the technology syllabus had been raised, were now demanding more and better access to resources of various kinds. Needs related to professional leadership and professional support were, in the majority of cases, being satisfied. The provision of adequate time for planning because of increased workload due to the advent of the new syllabus was an important initial and ongoing issue for a number of teachers. The concerns expressed by teachers about workload and time to fit a new subject into an already crowded school curriculum are similar to those identified by Thomson (2004) in her analysis of essential features of technology education in primary schools.

The findings also indicate that the totality of teachers' experiences enabled some teachers to make substantial changes to their teaching practice. For example, teachers became more aware of the need for students to have an understanding of the nature and properties of the materials they were working with before informed decisions could be made about the usefulness of those materials for the construction of artefacts. Controlled testing of the technological properties of materials eventuated from this approach. Positive experiences with problem solving approaches and the open-ended nature of those approaches were reported. Strategies for initiating problem solving and engaging students with technology processes included presenting students with design challenges and/or design briefs. As teachers grappled with judging student achievement, assessment criteria sheets were developed with the assistance of a researcher, and some teachers began to develop design portfolios for each 
Technology Education and Syllabus Implementation

student in her/his class. Overall, teachers reported raised standards in classroom technology activities. In particular, substantive conversations and improved student motivation were noted. Teachers linked these changed student behaviours to changes in their pedagogy from teacher focused to learner focused approaches.

What aspects emergent from the findings could be linked to twenty years of technology education and associated research on the essentials of classroom syllabus implementation? Many teachers at Farmland State School, when implementing the technology syllabus for the first time, encountered difficulties similar to those experienced by primary school teachers elsewhere. We too noted teachers' limited understandings of technology itself (Elton 2005; Jarvis \& Rennie 1996), limited understandings of technology concepts and processes (Holroyd \& Harlen 1996; Parkinson 2001), and they struggled to conceptualise technology within national and state frameworks (Mittell \& Penny 1997; Stein et al. 2002). Positive benefits for teachers appeared to accrue from a one day professional development program provided by the researchers in which materials and their properties were examined. This particular program had arisen from our own concerns about the importance of conceptual knowledge in technology, an issue examined by several researchers (e.g. Jones et al. 2001; McCormick 1997; McCormick 2004).

No substantive evidence of the recognition by teachers of the complexity of design processes (e.g. Johnsey 1995; Kimbell \& Parry 2001) could be observed in the collected data. During the 20 week period of the study there appeared to be an adherence to a sequential approach that embodied four elements (Investigation, Ideation, Production, and Evaluation) of the Technology Practice strand of the Queensland Technology syllabus. The Technology Practice strand had been emphasised strongly in professional development programs and it may have been too soon in terms of syllabus implementation for busy teachers to recognise the cyclic or recursive nature of technology processes. It is clear that, but the potential exists 
Technology Education and Syllabus Implementation

for a mindset to be established where a linear approach to designing becomes entrenched (Anning 1997). Strategies such as the use of design challenges and/or design briefs, which could be described as being part of the technology processes, were used to good effect by several teachers, mainly as a way of setting up problem solving scenarios for students. These scenarios could be identified as open-ended but focused teaching approaches (Twyford \& Jarvinen 2000), but there was no movement towards a problem based learning environment of the kind described by Doppelt (2003), and Doppelt and Barak (2002). The adoption of strategies such as design challenges, as well as the use of design portfolios can be attributed to teachers' experiences at professional development workshops. Teachers may benefit from the strategies suggested by Lee and Todd (2004), for example, the focused development of design criteria for an artefact, and the use of planning formats (Jones \& Moreland 2004). Group work was typically used by the teachers but lacked the refinement of collaborative learning as advocated by Hennessy and Murphy (1999), and few teachers allowed for student 'risk taking' in technological activity which is understandable at this early stage of syllabus implementation. Higher order thinking and questioning by the students of the kind suggested by Stables (1997) was noted but not capitalised on by the teachers during classroom interactions. Limited experiences with the technology syllabus and uncertainty about what to expect from students may have been reasons for teachers' reluctance to challenge students further to clarify their ideas or to think in-depth and creatively about solving problems.

\section{Conclusions}

Change, in the form of the introduction of a syllabus for a new learning area to a school, must be accompanied by effective support of various kinds so that all teachers become immersed in the content and processes of that learning area and acquire the capabilities and confidence to fully accept the challenges embodied in the implementation procedures. In this study, positive changes were noted in most teachers' personal perceptions of the syllabus 
Technology Education and Syllabus Implementation

implementation and their perceptions of the school environment. Important aspects of syllabus implementation procedures that may account for these changes were the teachers' engagement in a variety of professional development activities, and the strong support and commitment of the school principal to the full implementation of technology in Farmland school. At the stage the school had reached by the end of the research study, effective support must be provided to ensure the sustainability of the change.

It has been argued that twenty years of technology education and associated research has had some impact on the essentials of classroom syllabus implementation by teachers at Farmland State School. The impact can be traced through various forms of professional development activities teachers have engaged in and the teachers' capabilities as competent classroom practitioners. However, it is of concern that teachers were unable, did not have the time, or were not encouraged to capitalise on the rich discussions about, for example, technology itself, technology concepts and processes, and pedagogy issues, that have occurred over twenty years. This situation at Farmland State School may be representative of many primary schools in Queensland about to implement the Technology syllabus for the first time and may be similar to many schools elsewhere that have already implemented technology programs. It is suggested that ways of making this store of knowledge and expertise more meaningful and accessible to teachers must be found. Recommendations for capitalising on this store of knowledge and expertise follow.

- The particular needs of individual teachers must be determined in a systematic manner. In this study, the Technology Syllabus Implementation Questionnaire was a useful instrument for identifying the needs of teachers, in particular, the specific requirements of those who may need additional help. Teachers should be given opportunities to recognise that their needs are similar to those of their colleagues elsewhere as reported in the technology education research literature, as well as allowing them to reflect upon and 
Technology Education and Syllabus Implementation

discuss their own technological knowledge. In the Queensland context, with a new syllabus to be implemented by teachers inexperienced in the subject area, this represents an important first step in effective syllabus implementation that may not be as relevant in jurisdictions where technology is well established.

- Teachers' specific needs must be targeted with focused professional development programs. The planning and implementation of these focused programs should acknowledge and draw upon the relevant technology education literature and associated research. The style of professional development encountered in schools and reported in this paper is often of a 'generic' type that targets broad areas of need. At this stage of implementation, with a teacher workforce that does not have widely shared conceptions or experiences of the KLA, it is vital that the individual needs of teachers are recognised and acted upon, thus enabling all teachers to develop sufficient confidence and skills to enact the KLA. Focused professional development programs, for example, should provide scaffolding that will enable teachers to investigate and discover the uniqueness of technology in terms of content and processes, and enable them to recognise that technology practice can be used as a way of integrating the teaching of other subject areas such as science and mathematics, which may alleviate their concerns about time and an overcrowded curriculum.

- Establishment of collaborative learning networks for teachers that "reach in" and "reach out” are essential. The mentoring partnership with the QUT researchers provided timely, highly contextual support for the teachers at Farmland school. The features of this "reach in” relationship teachers appeared to benefit most from included help with planning and assessment and the presence of a researcher in the classroom to act as a source of ideas and a critical friend. It is noted that the support from the QUT researchers was meaningful and accessible but, in hindsight, more attention could have been paid to embedding that 
Technology Education and Syllabus Implementation

support in the technology education literature to ensure richer and more meaningful experiences for the teachers, for example, in providing advice about collaborative learning environments for students, ways of developing students' creativity and problem solving skills, and providing teachers with planning tools for teaching and assessment.

- A “reach out” learning network existed between Farmland State School and other schools in the cluster. The reach out nature of the network included the sharing of planning, assessment and project work with the cluster schools. A collaborative and supportive culture had been established that was in contrast to the previous culture of possession of resources and competition. The reach out learning network not only served to disseminate information, it strengthened the internal community but teachers could have benefited from an awareness of the relevant technology education literature.

It was evident that the strong, committed and supportive leadership from the school principal ensured the effective implementation of the Technology syllabus at Farmland school during the period of the study. Leadership of this kind was essential for the building of a community of practice in the school and the building of reach in and reach out learning networks that could eventually underpin the long-term implementation of the syllabus. Similarly, the potential success of the above suggestions for capitalising on the store of knowledge and expertise in technology education in any school situation may be dependent on strong leadership capabilities of the school principal and other school administrators

\section{References}

American Association for the Advancement of Science.: 1993. Benchmarks for Science Literacy: Project 2061, Oxford University Press, New York.

Anning, A.: 1994, 'Dilemmas and Opportunities of a New Curriculum: Design and Technology with Young Children', International Journal of Technology and Design Education 4, 155-177. 
Technology Education and Syllabus Implementation

Anning, A.: 1997, 'Teaching and Learning how to Design In Schools', The Journal of Design and Technology Education 2(1), 50-53.

Australian Education Council.: 1989, The Hobart Declaration on Schooling, Retrieved 1.8.2005 from http://www.mceetya.edu.au/hobdec.htm.

Australian Science Technology and Engineering Council.: 1997, Foundations for Australia's

Future. Science and Technology in Primary Schools, Australian Government Publishing Service, Canberra, ACT.

Barak, M., \& Doppelt, Y.: 2000, ‘Using Portfolios to Enhance Creative Thinking', Journal of Technology Studies 26(2), 16-24.

Board of Studies.: 1995, Technology - Curriculum and Standards Framework, Board of Studies, Carlton, Victoria.

Board of Studies.: 1991, Science and Technology K-6: Syllabus and Support Document, Board of Studies, Sydney, New South Wales.

Burgess, S.: 1998, 'Effects of Group Composition on Individual Learning/Performance in Design and Technology: A Case Study Approach', The Journal of Design and Technology Education 3(3), 201-208.

Curriculum Corporation.: 1994a, A statement on Technology for Australian Schools, Curriculum Corporation, Carlton, Victoria.

Curriculum Corporation.: 1994b, Technology - A Curriculum Profile for Australian Schools, Curriculum Corporation, Carlton, Victoria.

Custer, R.: 1995, 'Examining the Dimensions of Technology', International Journal of Technology and Design Education 5, 219-244.

DES/Wales.: 1990, Technology in the National Curriculum, HMSO, London.

Doppelt, Y.: 2003, 'Implementation and Assessment of Project-based Learning in a Flexible Environment', International Journal of Technology and Design Education 13, 255-272. 
Technology Education and Syllabus Implementation

Doppelt, Y., \& Barak, M.: 2002, 'Pupils Identify Key Aspects and Outcomes of a Technological Learning Environment', Journal of Technology Studies 28(1), 12-18.

Doornekamp, B. G.: 2001, 'Designing Teaching Materials for Learning Problem Solving in Technology Education', Research in Science \& Technological Education 19(1), 25 - 38.

Elton, F.: 2005, April, 'Technology Education in Chile after Nine Years of Implementation from the Paper to the Classroom', Proceedings of the PATT-15 Conference - Technology Education and Research: Twenty Years in Retrospect, (Retrieved 29.11 .05 from http://www.iteaconnect.org/PATT15/Elton.pdf), Haarlem, Netherlands.

Erickson, F.: 1998, ‘Qualitative Research Methods for Science Education’, in B. J. Fraser, \& K. G. Tobin, (eds.) International Handbook of Science Education, 1155-1173, Kluwer Academic Publishing, Dordrecht.

Ginestié, J.: 2002, 'The Industrial Project Method in French Industry and in French Schools', International Journal of Technology and Design Education 12(2), 99-122.

Hennessy, S., \& Murphy, P.: 1999, 'The Potential for Collaborative Problem Solving in Design and Technology’, International Journal of Technology and Design 9(1), 1-36.

Hill, A. M., \& Anning, A.: 2001, 'Primary Teachers’ and Students’ Understanding of School Situated Design in Canada and England', Research in Science Education 31(1), 117-135.

Holroyd, C., and Harlen, W.: 1996, 'Primary Teachers’ Confidence about Teaching Science and Technology’, Research Papers in Education: Policy and Practice 11(3), 323-335.

International Technology Education Association.: 2000, Standards for Technological Literacy: Content for the Study of Technology, International Technology Education Association, Reston, Virginia.

Jarvis, T., \& Rennie, L. J.: 1996, 'Perceptions about Technology held by Primary Teachers in England', Research in Science and Technological Education 14(1), 43-54. 
Technology Education and Syllabus Implementation

Johnsey, R.: 1995, 'The Design Process - Does it Exist? A Critical Review of Published Models for the Design Process in England and Wales', International Journal of Technology and Design Education 5, 199-217.

Jones, A., \& Moreland, J.: 2004, ‘Enhancing Practicing Primary School Teachers’ Pedagogical Content Knowledge in Technology', International Journal of Technology and Design Education 14(2), 121-140.

Jones, A., Moreland, J., \& Chambers, M.: 2001, March, 'Enhancing Student Learning in Technology through Enhancing Teacher Technological Literacy’, Paper presented at the Annual Meeting of the National Association for Research in Science Teaching, St Louis, MO.

Kimbell, R., Stables, K., \& Green, R.: 1996, Understanding Practice in Design and Technology, Open University Press, Buckingham.

Kimbell, R., \& Parry, D.: 2001, Design and Technology in the Knowledge Economy, Engineering Council, London.

Lee, J, \& Todd, R.: 2004, March, 'Clarifying the Design Task - Developing a 'Toolkit' for Teachers and Pupils', Proceedings of the PATT-14 Conference - Pupils’ Decision Making in Technology: Research, Curriculum Development and Assessment, (Retrieved 1.8.2005 from http://www.iteaconnect.org/PATT14/PATT14.pdf), Albuquerque, New Mexico, USA.

Lewthwaite, B.: 2004, ““Are You saying I'm to Blame?” Exploring the Influence of a Principal on Elementary Science Delivery’, Research in Science Education 34(2), 137-152. Lincoln, Y. S., \& Guba, E. G.: 2000, 'Paradigmatic Controversies, Contradictions, and Emerging Confluences’, In N. K. Denzin \& Y. S. Lincoln (eds.), Handbook of Qualitative Research (2nd ed.), 163-188, Sage, Thousand Oaks, CA. 
Technology Education and Syllabus Implementation

McCormick, R.: 2004, 'Issues of Learning and Knowledge in Technology Education', International Journal of Technology and Design Education 14(1), 21-44.

McCormick, R.: 1997, 'Conceptual and Procedural Knowledge’, International Journal of Technology and Design Education 7, 141-159.

McCormick, R., \& Davidson, M.: 1996, 'Problem Solving and the Tyranny of Product Outcomes’, Journal of Design and Technology Education 1(3), 230-241.

McRobbie, C. J., Stein, S. J., \& Ginns, I.: 2001, ‘Exploring Designerly Thinking of Students as Novice Designers’, Research in Science Education 31(1), 91-116.

McRobbie, C., Ginns, I., \& Stein, S.: 2000, 'Preservice Primary Teachers' Thinking about Technology and Technology Education', International Journal of Technology and Design Education 10(1), 81-101.

McRobbie, C., Stein, S., \& Ginns, I.: 2000, April/May, 'Elementary School Students' Approaches to Design Activities', Paper presented at the Annual Meeting of the National Association for Research in Science Teaching, New Orleans, LA.

Mittell, I., \& Penny, A.: 1997, 'Teacher Perceptions of Design and Technology: A Study of Disjunction between Policy and Practice’, International Journal of Technology and Design Education, 7 279-293.

Murphy, P., \& Hennessy, S.: 2001, 'Realising the Potential - and Lost Opportunities for Peer Collaboration in a D \& T Setting', International Journal of Technology and Design Education 11(3), 203-237.

Parkinson, E.: 2001, 'Teacher Knowledge and Understanding of Design and Technology for Children in the 3-11 Age Group: A study focusing on aspects of structures', Journal of Technology Education 13(1), 44-57. 
Technology Education and Syllabus Implementation

Queensland Schools Curriculum Council.: 1998, Years 1-10 Technology Key Learning Area Curriculum Development Project: Design Brief (Part 2), Queensland Schools Curriculum Council, Brisbane.

Queensland Studies Authority.: 2003, Technology: Years 1 to 10 Syllabus, Queensland Studies Authority, Brisbane.

Stables, K.: 1997, 'Critical Issues to Consider when Introducing Technology Education into the Curriculum of Young Learners', Journal of Technology Education 8(2), 50-65.

Stein, S. J., McRobbie, C. J., \& Ginns, I. S.: 2002, 'Implications of Missed Opportunities for Learning and Assessment in Technology Education', Teaching and Teacher Education 18(1), 35-49.

Thomson, C.: 2004, March, 'What are the Unique and Essential Characteristics of Technology Education in the Primary School? A Study Based in the USA', Proceedings of the PATT-14 Conference - Pupils’ Decision Making in Technology: Research, Curriculum Development $\begin{array}{llll}\text { and } & \text { Assessment, } & \text { (Retrieved } & \text { from }\end{array}$ http://www.iteaconnect.org/PATT14/PATT14.pdf), Albuquerque, New Mexico, USA.

Twyford, J., \& Jarvinen, E.: 2000, ‘The Influences of Socio-cultural Interaction upon Children’s Thinking and Actions in Prescribed and Open-ended Problem Solving Situations: An Investigation Involving Design and Technology Lessons in English and Finnish Primary Schools', International Journal of Technology and Design Education 10(1), 21-41.

Welch, M.: 1999, ‘Analyzing the Tacit Strategies of Novice Designers’, Research in Science and Technological Education 17(1), 19-34.

Welch, M., \& Lim, H. S.: 2000, 'The Strategic Thinking of Novice Designers: Discontinuity between Theory and Practice’, Journal of Technology Studies 26(2), 34-44.

Welch, M., Barlex, D., \& Lim, H. S.: 2000, 'Sketching: Friend or Foe to the Novice Designer', International Journal of Technology and Design Education 10(2), 125-148. 
Technology Education and Syllabus Implementation

Wilson, V., \& Harris, M.: 2003, 'Designing the Best: A Review of Effective Teaching and Learning of Design and Technology', International Journal of Technology and Design Education 13, 223-241. 
Technology Education and Syllabus Implementation

\section{About the authors}

\section{Dr Ian Ginns}

Ian Ginns is senior lecturer in science education in the Faculty of Education at the Queensland University of Technology. His research interests include design and technology education, and preservice and beginning teachers' beliefs about their ability to teach science.

Fax:

+61 738643985

Email (W): $\quad$ i.ginns@qut.edu.au

Email (H): $\quad$ ginnsfamily@aapt.net.au

Telephone (W): $\quad$ +61738643339

Telephone (H): $\quad$ +61 $\quad$ 6133536864

\section{Dr Stephen Norton}

Dr Norton has been recently appointed as a lecturer in mathematics and science education in the School of Curriculum, Teaching and Learning at Griffith University. His research interests include investigating the integrated teaching of mathematics and science through technology practice.

Fax: $\quad$ +61 $\quad$ +6133821104

Email: $\quad$ s.norton@griffith.edu.au

Telephone (W): $\quad$ +61733821362

\section{Emeritus Professor Campbell McRobbie}

Cam McRobbie currently conducts research in the Centre for Learning Innovation at Queensland University of Technology. He has an extensive research background in education, focusing on learning environments, students' learning and teacher change, and design and technology education.

Fax: +61738643985

Email: $\quad$ c.mcrobbie@qut.edu.au 
Technology Education and Syllabus Implementation

Telephone (W): $\quad$ +61738643333

\section{Dr Robert Davis}

Dr Rob Davis was appointed recently as a lecturer in the School of Education, at the University of Ballarat, Victoria. Rob's research interests focus on the assessment of technology content and processes in the classroom, and the professional development of teachers.

Fax: $\quad$ +61353279738

Email: $\quad$ rs.davis@ballarat.edu.au

Telephone (W): +61353279726 